\title{
Characterization of the protein fraction of the extracellular polymeric substances of three anaerobic granular sludges
}

\author{
Charles-David Dubé ${ }^{1,2}$ and Serge R. Guiot ${ }^{1,2^{*}}$ (D)
}

\begin{abstract}
Extracellular polymeric substances (EPS) play major roles in the efficacy of biofilms such as anaerobic granules, ranging from structural stability to more specific functions. The EPS of three granular anaerobic sludges of different origins were studied and compared. Particularly, the peptides from the protein fraction were identified by mass spectrometry. Desulfoglaeba and Treponema bacterial genera and Methanosaeta and Methanobacterium archaeal genera were prominent in all three sludges. Methanosaeta concilii proteins were the most represented in EPS of all three sludges studied. Principally, four proteins found in the three sludges, the S-layer protein, the CO-methylating acetyl-CoA synthase, an ABC transporter substrate-binding protein and the methyl-coenzyme M reductase, were expressed by Methanosaeta concilii. Mainly catabolic enzymes were found from the 45 proteins identified in the protein fraction of EPS. This suggests that EPS may have a role in allowing extracellular catabolic reactions.
\end{abstract}

Keywords: Anaerobic granule, Extracellular polymeric substances, Humic substances, Proteins, Mass spectrometry

\section{Introduction}

The biofilm is the best-known community lifestyle for microorganisms. Extracellular polymeric substances (EPS) embed biofilm cells, thus play an important role in the biofilm development and cohesion. The EPS macromolecules are either excreted by microorganisms, produced from cell lysis, or adsorbed from the external environment (e.g. wastewater) (Sheng et al. 2010). EPS include mostly proteins, carbohydrates, humic substances (HS) and nucleic acids. The question of which microbial species participates most in mixed species biofilm matrix construction remains, in most cases, unclear.

Anaerobic sludge granules are small spherical biofilms, which contain the different microbial groups typically found in anaerobic digestion consortia. Each group performs specialized metabolic functions sequentially leading to the transformation of the primary substrate ultimately into methane and $\mathrm{CO}_{2}$. Compared to

\footnotetext{
*Correspondence: serge.guiot@umontreal.ca

${ }^{2}$ Department of Microbiology, Infectiology and Immunology, Université de Montréal, 2900 Boul. Édouard-Montpetit, Montreal H3T 1J4, Canada Full list of author information is available at the end of the article
}

aerobic granules, anaerobic granules have a longer startup period (2-8 months) but they have a much stronger stability (Ding et al. 2015; Liu et al. 2004). However, for both granules types, their EPS content has been found much higher than in any other biofilm types (Tay et al. 2001). EPS are known to be important in the maintenance of granule stability and cohesion (Ding et al. 2015; MacLeod et al. 1995). The EPS matrix can also trap extracellular catalytic enzymes and keep them in close proximity to the cells (Zhang et al. 2015). EPS can protect the cells against oxygen and toxic compounds, allow for sorption of organic and inorganic compounds, act as an electron donor and acceptor, and facilitate communication among the cells through biochemical signals as well as gene exchange (Flemming and Wingender 2010).

In most anaerobic sludge systems, the largest fraction of EPS extracts are proteins, which significantly contribute to the granule formation (Zhu et al. 2015). EPS extracts from aerobic and anaerobic granules have quite the same characteristics; they both have proteins as the main EPS fraction and a protein/carbohydrate (PN/PS) ratio in EPS from 1 up to 12. However, what seems to 
differentiate the anaerobic granules from the aerobic ones is the presence of an important fraction of HS (Ding et al. 2015). Proteins from aerobic sludge EPS had previously been studied by sodium dodecyl sulfate polyacrylamide gel electrophoresis (SDS-PAGE) and mass spectrometry (Park et al. 2008; Zhang et al. 2007), but never those from anaerobic sludge. The identification of these proteins and their origin could help us to clarify the hypothetical roles of EPS and better understand the microbial ecology of anaerobic granular biofilms and the adhesion mechanisms behind granules formation in upflow anaerobic sludge blanket (UASB) reactors.

This study focuses on comparison of three anaerobic granular sludges treating different industrial effluents. The first objective was to characterize their populations in order to comprehensively assess species ubiquity and specificity among the different granule types. The second objective was to extract and identify EPS proteins of each granule type and correlate these findings to the microbial species characterization in order to better understand the roles that EPS and these species could play within the anaerobic granules in relation to the different feed substrates.

\section{Materials and methods}

\section{Sources of sludge and preparation}

The anaerobic granular sludge samples used in this study came from three large-scale reactors of the UASB type, treating industrial wastewater. The three companies were Agropur, a cheese factory, Lassonde, a fruit juice factory, and Tembec, a pulp and paper mill, respectively (Table 1). Sludge was stored at $4{ }^{\circ} \mathrm{C}$ until experiments. Before experiments, sludge was rinsed with anoxic carbonate buffer of $\mathrm{pH} 7.0$ containing $(\mathrm{g} / \mathrm{L}) \mathrm{NaHCO}_{3}(10), \mathrm{NH}_{4} \mathrm{Cl}$ (0.5), $\mathrm{KH}_{2} \mathrm{PO}_{4}(0.3)$ and $\mathrm{K}_{2} \mathrm{HPO}_{4}(0.4)$ (Dolfing and Mulder 1985), to remove free cells and debris. To determine the dry weight (DW) and the volatile dry weight (VDW) of the sludge, samples were heated overnight at $105^{\circ} \mathrm{C}$ and $1 \mathrm{~h}$ at $600{ }^{\circ} \mathrm{C}$, respectively (Eaton et al. 2005).

\section{Microbial community analysis by high throughput screening (HTS)}

Total genomic DNA was extracted from the sludges samples using the PowerSoil ${ }^{\mathrm{TM}}$ DNA isolation kit (Mobio Laboratories, Carlsbad, CA) according to the manufacturer's instructions. Bacterial 16S rRNA genes were amplified using the set of primers E786F ( $5^{\prime}$ GATTAG ATACCCTGGTAG $3^{\prime}$ ) and U926R (5' CCGTCAATT CCTTTRAGTTT 3') (El Fantroussi et al. 1998). Archaeal 16S rRNA genes were amplified using the set of primers 958arcF ( $5^{\prime}$ AATTGGANTCAACGCCGG $3^{\prime}$ ) and an equimolar mix of 1048arcR-major ( $5^{\prime}$ CGRCGGCCA TGCACCWC $3^{\prime}$ ) and 1048arcR-minor (5' CGRCRGCCA
TGYACCWC 3') (Hadjeb and Berkowitz 1996). A sample-specific multiplex identifier was added to each forward primer and an Ion Torrent adapter (Thermo Fisher Scientific, Waltham, MA) was added to each primer. The polymerase chain reaction (PCR) amplification reactions were performed as described previously (Hussain et al. 2014) using the rTaq DNA polymerase (GE Healthcare, Life Sciences Piscataway, NJ). The PCR products were purified and quantified using a QIAquick gel extraction kit (Qiagen, Valencia, CA) and a Quant-iT PicoGreen double-stranded DNA quantitation kit (Life Technologies Inc., Carlsbad, CA), respectively, according to the manufacturer's instructions. The pooled bacterial and archaeal 16S rRNA gene amplicons were then sequenced using Ion Torrent sequencing platform with a 314 chip, according to the manufacturer's instructions. For sequencing analysis, bacterial and archaeal 16S rRNA gene sequences generated were analyzed using the ribosomal database project (RDP) classifier (Schmidt 1986) using bootstrap confidence cutoffs of $50 \%$, as recommended by the RDP classifier for short sequences (less than $250 \mathrm{bp}$ ) (Juteau et al. 1995). Sequences that were shorter than $75 \mathrm{bp}$ and sequences with unidentified bases $(\mathrm{N})$ were removed from the analysis. Sequences have been deposited in NCBI database (accession number PRJNA498054).

\section{EPS extraction}

Sonication (Sonics Vibra Cell VC130, probe CV18 3987, Sonics \& Materials Inc., Newtown, CT) was used for granules disruption and EPS extraction. Various times of sonication $(2,4,8$ and $12 \mathrm{~min})$ at $30 \mathrm{~W}(1 \mathrm{~W} / \mathrm{mL})$ were compared. After 2 and $4 \mathrm{~min}$, a large number of intact granules were still recovered, meaning that extraction was too short to break down all granules. The amount of EPS extracted tended to increase with the sonication duration. However this tendency faded between 8 and $12 \mathrm{~min}$, and after $8 \mathrm{~min}$ of sonication, no intact granules could be recovered. We thus considered that the optimal sonication time to obtain EPS was 8 min and longer sonication times would likely affect the cell integrity. The PN/ PS ratio had a slight tendency to decrease with increasing time of granule exposure to sonication (variance of $27 \%$ between the four times tested).

After rinsing and removal of the water excess, $15 \mathrm{~g}$ of wet granules were added to $15 \mathrm{~mL}$ of carbonate buffers and then sonicated at $30 \mathrm{~W}(1 \mathrm{~W} / \mathrm{mL})$ for $8 \mathrm{~min}$. Sonication was performed on ice with a 2 min interval between each $2 \mathrm{~min}$ of sonication, to prevent overheating. The sonicated samples were then centrifuged at $15,000 \times g, 3$ times 15 min (Sorvall RC6Plus, Thermo Electron Corporation, Waltham, Massachusetts). The supernatant containing EPS were frozen at $-20{ }^{\circ} \mathrm{C}$ until further characterization or directly used for precipitation steps (see 


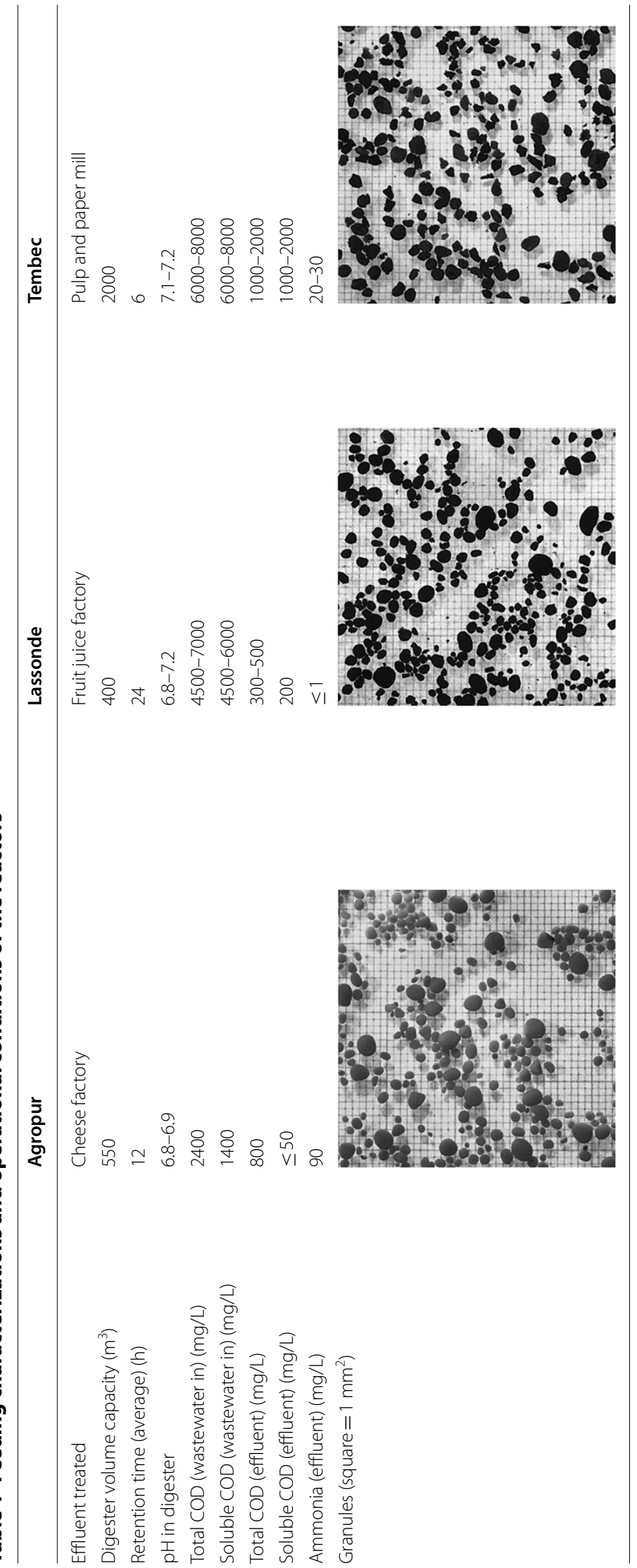


SDS-PAGE section) and cell lysis detection. Each EPS extraction, cell lysis detection and characterization was done in triplicate for each sludge. The triplicates were pooled together prior the gel electrophoresis and mass spectrometry.

\section{Cell lysis detection}

Sonication could damage the cell membrane and induce cell lysis, depending on the strength and duration of sonication (Picard et al. 1992). Glucose-6-phosphate dehydrogenase (G6PDH) (G8404, Millipore Sigma, ON, CA) activity was measured on EPS extract to evaluate the cell lysis during the sonication (Monique et al. 2008). $800 \mu \mathrm{L}$ of enzymatic substrate solution $(0.2 \mathrm{M}$ Tris- $\mathrm{HCl}$, $0.2 \mathrm{M} 2$ mercaptoethanol, $0.5 \mathrm{mM} \mathrm{NAD}, 10 \mathrm{mM}$ D-glucose-6-phosphate, $\mathrm{pH}$ 8.5) were added to $200 \mu \mathrm{L}$ of each extract. The absorbance was measured at $340 \mathrm{~nm}$ at room temperature every $35 \mathrm{~s}$ using UV1 (Thermo Spectronic) for $10 \mathrm{~min}$ to measure NADH production. $1 \mathrm{U}$ of G6PDH gives $1 \mathrm{nmol}$ of $\mathrm{NADH}$ produced per minute, and it is equivalent to approximately $5 \times 10^{6}$ lysed cells, or $20 \mathrm{ng}$ of dry lysed cells (Ras et al. 2011).

\section{Characterization of EPS}

DW and VDW of EPS extracts were determined as mentioned above to calculate yields of extraction. Protein, carbohydrate, humic substance and nucleic acid fractions were determined by colorimetric methods. All measurements were done using a DR 3900 spectrophotometer (Hach, London, ON, CA). Carbohydrates were determined following the Dubois' protocol (Dubois et al. 1956) and nucleic acids, the Burton's protocol (Burton 1956). Proteins and humic substances were determined using Lowry-based Frølund's method (Frølund et al. 1995; Lowry et al. 1951), modified as detailed in the Additional file 1: Figures S1, S2.

\section{Separation using gel electrophoresis}

Prior separation on sodium dodecyl sulfate polyacrylamide gel electrophoresis (SDS-PAGE), sequential precipitations of EPS extracts were done to roughly separate the protein from the HS fraction, which precipitates at lower salt concentration (Park and Helm 2008). Ammonium sulfate was stepwise added from 0.2 to $0.6 \mathrm{~g} / \mathrm{mL}$ $(+0.1 \mathrm{~g} / \mathrm{mL}$ at each step), incubated for at least $6 \mathrm{~h}$ at $4{ }^{\circ} \mathrm{C}$ and then centrifuged at $20,000 \times g, 30 \mathrm{~min}$ at $4{ }^{\circ} \mathrm{C}$. The centrifugation pellets were resuspended in $1.5 \mathrm{~mL}$ of carbonate buffers. SDS-PAGE (Laemmli 1970) were done on $4-12 \%$ bis-tris polyacrylamide gels and coloured with Coomassie blue (Bio-rad, Mississauga, ON, CA). During the EPS precipitation steps with ammonium sulfate, humic substances tended to precipitate in fractions with between 0 and $0.3 \mathrm{~g}\left(\mathrm{NH}_{4}\right)_{2} \mathrm{SO}_{4} / \mathrm{mL}$ while proteins predominated in the other fractions, with 0.4 to $0.6 \mathrm{~g}\left(\mathrm{NH}_{4}\right)_{2} \mathrm{SO}_{4} / \mathrm{mL}$. Bands of proteins appeared in the last three fractions (i.e. with 0.4 to $0.6 \mathrm{~g}\left(\mathrm{NH}_{4}\right)_{2} \mathrm{SO}_{4} / \mathrm{mL}$ ). Those three fractions were pooled and passed on the gels.

\section{Mass spectrometry (MS)}

The more representative protein bands (shown on Fig. 1) were cut from the gel for each sample (about 8 bands per sample). Bands were detained with water/sodium bicarbonate buffer and acetonitrile. The protein fragments were reduced with dithiothreitol (DTT) and alkylated with iodoacetamide prior to in-gel digestion with trypsin. The tryptic peptides were eluted from the gel with acetonitrile containing $0.1 \%$ of tri-fluoro-acetic acid and then separated on an Agilent Nanopump using a C18 ZORBAX trap and a SB-C18 ZORBAX 300 reversed phase column $(150 \mathrm{~mm} \times 75 \mu \mathrm{m}, 3.5 \mu \mathrm{m}$ particle size $)$ (Agilent Technologies Inc., Santa Clara, CA). All mass spectra were recorded on a hybrid linear ion trap-triple quadrupole mass spectrometer (Q-Trap, Applied Biosystems, MDS SCIEX Instruments, Concord, ON, CA) equipped with a nano-electrospray ionization source. The accumulation of tandem mass spectrometry (MS/ MS) data was performed with the Analyst Software, version 1.4 (Applied Biosystems, MDS SCIEX). MASCOT (Matrix Science, London, UK) was used to create peak lists from MS to MS/MS raw data. Only individual ion scores that indicate identity or extensive homology $(\mathrm{p}<0.05)$ and only proteins with at least one significant sequence were kept for interpretation.

\section{Results}

\section{Microbial populations}

The molecular-based profiles of the microbial communities were first determined in the three anaerobic sludges under investigation (i.e. Agropur, cheese factory; Lassonde, juice industry; Tembec, paper mill), using high throughput screening (HTS). Those three sludges were chosen because they treat wastewaters of various origins, that we know could have a great impact on microbial populations and EPS composition (Liu et al. 2004; Sheng et al. 2010). Results are shown in Table 2. Some genera found at high levels in some sludge were totally absent in others. This is the case for the bacterial genera Mesotoga and Syntrophobacter (absent in the Tembec sludge), Propioniciclava (absent in the Agropur and Tembec sludges), Desulfovirga (absent in the Lassonde sludge). On the other hand, bacterial genera such as Desulfoglaeba and Treponema were relatively abundant in all sludges. Yet a large percentage of bacterial genera remained unknown (between 60 and 68\%) in the anaerobic granules within 
this study, meaning that anaerobic processes remain to a large extent a black box of diversified and complex populations. On the archaeal side, the three sludges seem to have the acetoclastic and hydrogenophilic (including formate consumers) populations well balanced, with the genus Methanosaeta and the classes Methanobacteriales or Methanomicrobiales amply present in all sludges. The genera Methanolinea and Methanomethylovorans were absent in the Tembec and Lassonde sludges, respectively. No Methanosarcina has been found in any sludge studied.

\section{EPS}

A variety of physical and chemical methods have been proposed for EPS extraction, with variable results in terms of extraction yield of the extract (D'Abzac et al. 2010; Pellicer-Nàcher et al. 2013; Sheng et al. 2010). In our study, it was a physical extraction method that was chosen, since this is what was recommended in other studies on sludge proteome (Zhang et al. 2015; Park et al. 2008; Zhu et al. 2015). Although the yield differs according to the physical method used, the extracts show very similar IR spectra (Comte et al. 2006, D'Abzac et al. 2010), which guarantees their similarity. Glucose6-phosphate dehydrogenase (G6PDH) activity was measured on EPS extract to evaluate the cell lysis during the sonication (Monique et al. 2008). No G6PDH activity was detected in extracts as shown in Table 3, while phasecontrast microscopy clearly showed alive cells after $8 \mathrm{~min}$ of sonication (Additional file 1: Figure S3). Composition of EPS extracted from three different anaerobic sludges is listed in Table 4. The EPS represented 31\%, 20\% and $14 \%$ of the dry weight (DW) of Agropur, Lassonde and Tembec sludge, respectively. The EPS compound with the smallest fraction was nucleic acids, followed by carbohydrates, while the protein fraction always represented the main compound, and HS, the second most important EPS constituent, for all sludges. Proteins and HS represent by consequence the core of this matrix where cells are embedded. The PN/PS ratio was 3, 3 and as high as 6 for Lassonde, Agropur and Tembec sludge, respectively.

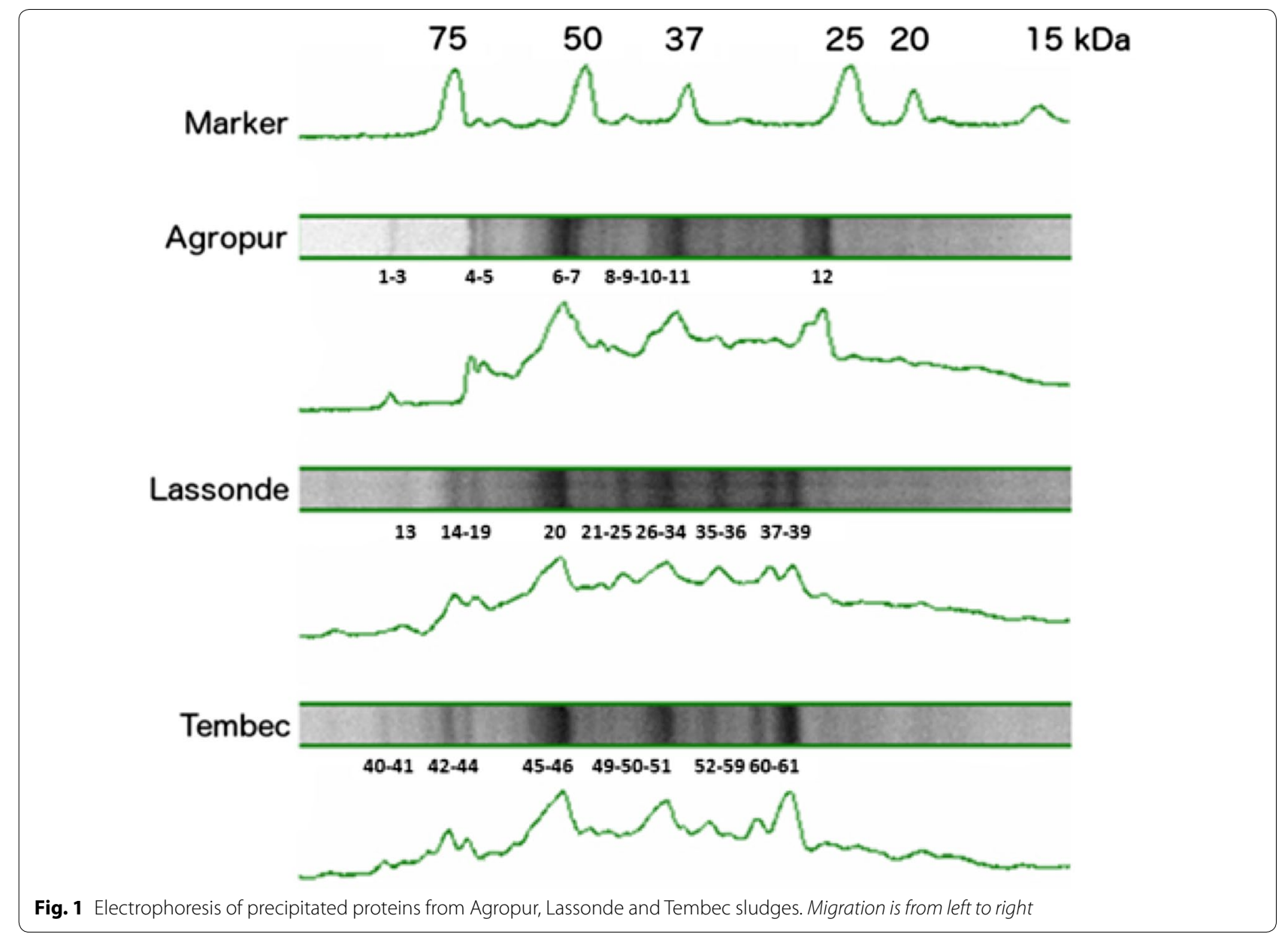


Table 2 Relative abundance of bacterial and archaeal genera for each sludge

\begin{tabular}{|c|c|c|c|}
\hline Sludge origin & Agropur (\%) & Lassonde (\%) & Tembec (\%) \\
\hline \multicolumn{4}{|l|}{ Bacteria } \\
\hline Desulfoglaeba & 18 & 3 & 2 \\
\hline Mesotoga & 8 & 3 & 0 \\
\hline Propioniciclava & 0 & 7 & 7 \\
\hline Syntrophobacter & 5 & 1 & 0 \\
\hline Propionibacterium & 0 & 4 & 1 \\
\hline Desulfovibrio & 0 & 1 & 4 \\
\hline Treponema & 3 & 3 & 4 \\
\hline Aminivibrio & 1 & 2 & 4 \\
\hline Desulfomicrobium & 0 & 2 & 3 \\
\hline Syntrophorhabdus & 3 & 1 & 2 \\
\hline Smithella & 0 & 2 & 1 \\
\hline Olsenella & 0 & 0 & 2 \\
\hline Alkalibaculum & 0 & 0 & 2 \\
\hline Propionivibrio & 0 & 1 & 1 \\
\hline Brooklawnia & 0 & 1 & 0 \\
\hline Syntrophobotulus & 0 & 0 & 1 \\
\hline Thermovirga & 0 & 0 & 1 \\
\hline Sporobacter & 0 & 0 & 1 \\
\hline Gaiella & 1 & 0 & 0 \\
\hline Cloacibacillus & 0 & 0 & 1 \\
\hline Propionicimonas & 0 & 1 & 0 \\
\hline Flavonifractor & 0 & 1 & 0 \\
\hline Syntrophus & 0 & 0 & 1 \\
\hline Aminiphilus & 0 & 0 & 1 \\
\hline Streptomyces & 0 & 1 & 0 \\
\hline Petrimonas & 0 & 0 & 1 \\
\hline Pelolinea & 0 & 0 & 0 \\
\hline Other or unknown & 60 & 68 & 66 \\
\hline \multicolumn{4}{|l|}{ Archaea } \\
\hline Methanosaeta & 57 & 36 & 48 \\
\hline Methanobacterium & 9 & 47 & 23 \\
\hline Methanolinea & 25 & 6 & 0 \\
\hline Methanomethylovorans & 3 & 0 & 8 \\
\hline Methanomassiliicoccus & 1 & 1 & 2 \\
\hline Other or unknown & 6 & 10 & 18 \\
\hline
\end{tabular}

\section{Proteins in EPS}

Proteins precipitation was done with EPS extracts prior separation on gels as shown in Fig. 1. The migration patterns were slightly different from one sludge to the other, but there were still bands of the same molecular weight in the 3 sludges. Proteins were ranging 26-89 $\mathrm{kDa}$. Those results are consistent with previous studies (Zhu et al. 2015) where a thermal EPS extraction was used. After $3,3^{\prime}, 5,5^{\prime}$-tetramethylbenzidine (TMBZ) staining (Jensen et al. 2010), no metalloprotein (such as cytochromes) were detected on gels. The most representative bands on SDS-PAGE gels were cut and analyzed by HPLC-tandem mass spectrometry for protein identification. Additional file 1: Table S1 presents significant proteins that were identified. Four proteins were found in every sludge tested: the $\mathrm{S}$-layer protein, the $\mathrm{CO}$-methylating acetyl-CoA synthase complex (CODH/AC synthase), an $\mathrm{ABC}$ transporter substrate-binding protein and the coenzyme-B sulfoethylthiotransferase, also known as methyl-coenzyme $\mathrm{M}$ reductase (MCR). A total of 45 proteins from more than 50 species of archaea and bacteria have been identified (Table 5). Methanosaeta concilii is by far the microorganism that has been the most represented by this overall proteomic search. The Agropur sludge (cheese factory) was the less diversified sludge with only 31 positive hits and 17 proteins found, instead of 52 and 64 hits or 33 and 39 proteins found, for the Lassonde and Tembec sludge, respectively. It should also be mentioned that many sequenced peptides were not associated with any known organism or known protein, as already highlighted with the bacterial HTS results.

\section{Discussion}

The EPS represent an important proportion of the granule studied, with from $14 \%$ to $31 \%$ by dry weight. Proteins were the main constituents. MS results show that most of the proteins identified were related to catalytic activities. Shotgun proteomic analysis of the cation exchange resin extracted EPS fraction from anaerobic sludge had reached the same conclusion (Zhang et al. 2015). This predominance of catabolic enzymes shows

Table 3 Cell lysis detection assays

\begin{tabular}{lllll}
\hline & Negative control (buffer) & $\begin{array}{l}\text { Positive controls (1.12 G6PDH } \\
\text { units) }\end{array}$ & $\begin{array}{l}\text { Positive controls incubate } \\
\text { with samples }\end{array}$ & All samples \\
\hline $\begin{array}{c}\text { Activity slope (unit of absorbance } \\
(430 \mathrm{~nm}) \text { per second) }\end{array}$ & $0.0000 \pm 0.0000$ & $0.0168 \pm 0.0010$ & $0.0168 \pm 0.0003$ & $0.0000 \pm 0.0000$ \\
\hline
\end{tabular}

Positive controls contained 1.12 units of glucose-6-phosphate dehydrogenase (G6PDH) in buffer. Positive controls incubated with cells samples were to test inhibitors presence in samples 
Table 4 Compound classes of EPS extracted

\begin{tabular}{|c|c|c|c|}
\hline Sludge origin & Agropur & Lassonde & Tembec \\
\hline EPS/sludge [mg/g, DW] & $311 \pm 22$ & $195 \pm 6$ & $143 \pm 3$ \\
\hline EPS/sludge [mg/g, VDW] & $310 \pm 33$ & $151 \pm 7$ & $132 \pm 3$ \\
\hline Proteins EPS/sludge (mg/g, VDW) & $124 \pm 13$ & $46 \pm 17$ & $66 \pm 4$ \\
\hline $\begin{array}{l}\text { Humic substances EPS/sludge (mg/g, } \\
\text { VDW) }\end{array}$ & $44 \pm 6$ & $36 \pm 6$ & $47 \pm 4$ \\
\hline Carbohydrate EPS/sludge (mg/g, VDW) & $37 \pm 11$ & $16 \pm 1$ & $11 \pm 1$ \\
\hline Nucleic acids EPS/sludge (mg/g, VDW) & $16 \pm 1$ & $6 \pm 1$ & $6 \pm 0$ \\
\hline Protein/carbohydrate ratio & 3 & 3 & 6 \\
\hline
\end{tabular}

that the EPS matrix has the capacity for extracellular catabolic reactions, which represents a competitive advantage for anaerobic granules. After proteins, HS represent the second larger constituents of EPS. The HS of EPS could come from the biomass degradation or/and from polycondensation of relatively small molecules released during biomass decay, but also from synthesis by the microorganisms themselves (Claus et al. 1999). Their role in the microbial aggregates has not yet been clearly explained. HS in anaerobic environment may act as a reducing agent for electron transfer (Klüpfel et al. 2014; Roden et al. 2010; Voordeckers et al. 2010) and as such, promote direct interspecies electron transfer (DIET). As proteins extracted were mostly related to metabolism, HS are then the next candidate to play the structural role expected by EPS.

The variation in genera from one sludge to another is probably mainly due to the difference in the substrates composing the wastewater treated by the sludge, which can be preferentially consumed by one genus rather than another. Methanosaeta concilii is the microorganism for which the most protein hits were obtained regardless of the sludge origin. This archaeon has been reported as having a key role in the granulation (Hulshoff Pol et al. 2004). In most of granulation theories, Methanosaeta is largely associated with the first step of granulation, because it produces long filaments. S-Layer duplication domain protein from Methanosaeta concilii was found in the three protein extracts. S-Layer duplication domain protein is one of the primary proteins of the S-layer in archaea (Fagan and Fairweather 2014; Sara and Sleytr 2000). The archaeal S-layer proteins are known to have a structural role and to be involved in cell adhesion and population cohesion (De Vrieze et al. 2012). S-Layer proteins are typically highly glycosylated, leading to the formation of bonds between polysaccharides and proteinic EPS fractions (Sleytr and Beveridge 1999). The $\mathrm{MCR}$ and $\mathrm{CODH} /$ acetyl-CoA (CODH/AC) synthase enzymes were the other major proteins found in all sludges. MCR is an enzyme responsible for the last step of methanogenesis, combining the methyl group of coenzyme $\mathrm{M}$ with hydrogen from the coenzyme B to form methane (Balch et al. 1979). The CODH/AC synthase works primarily through the Wood-Ljungdahl pathway which converts $\mathrm{CO}_{2}$ to acetyl-CoA (Ragsdale and Pierce 2008). Archaeal methanogens, particularly Methanosaeta, largely predominate in the innermost layer of the granule (MacLeod et al. 1990; Sekiguchi et al. 1999). It is therefore expected that most dead archaea are also located in the granule centre, where they can accumulate, since they are confined in that remote zone of the EPS matrix and that they would be released in abundance during the sonication extraction. In this respect, Agropur granules typically were of light grey colour, indicating the lesser importance of such a usually dark methanogenic core; this would explain the lowest number of archaeal enzyme found in the EPS of Agropur granules.

The MCR and CODH/AC synthase enzymes are extremely sensitive to oxygen. When oxidized they are deactivated and could not be regenerated (Cedervall et al. 2010). Either the cell decomposes the deactivated enzymes for recycling, or simply excretes them, as recycling could cost too much energy. The presence of a large amount of MCR and CODH/AC synthase in EPS could then be a marker of oxygen stress undergone by methanogens. Small oxygen levels added in anaerobic reactors do not affect the methane production, however longterm exposure to $\mathrm{O}_{2}$ leads to smaller granule sizes in the reactors (Stephenson et al. 1999).

Among the other identified proteins, the glyceraldehyde 3-phosphate dehydrogenase (GAPDH) was largely found in Lassonde sludge and originating from many bacterial strains (Table 5). It actually represents the principal hit for bacterial strains overall the three sludges. GAPDH is an essential enzyme during glycolysis but it also has several other roles. It has been detected at the surface of several prokaryotes (Oliveira et al. 2012; Pancholi and Chhatwal 2003) as an adhesion and binding protein (Brassard et al. 2004). It binds albumin and several other mammalian proteins (Jin et al. 2005) and it is now considered as a virulence factor for some bacterial strains (Seidler 2013). GAPDH is required for EPS production in Xanthomonas proteobacteria ( $\mathrm{Lu}$ et al. 2009). As a protein with multiple roles, GAPDH could play a role in granulation and in maintaining the granule integrity. Fasciclin domain proteins also have an important role in cell adhesion (Moody and Williamson 2013) and have been found expressed by Methanosaeta concilii in Tembec sludge.

Bacterial formate dehydrogenase (FDH) was identified from Agropur sludge proteins. This FDH is associated with molybdenum (Mo) or tungsten (W) and is NAD-independent. This enzyme catalyzes the reduction of $\mathrm{CO}_{2}$ using reducing equivalents coming from the upstream degradation of the primary substrate. 
Table 5 Identified proteins and microbial species that produce them, in the EPS of the three tested sludges

\begin{tabular}{|c|c|c|}
\hline Description & Species & Sludge \\
\hline $\begin{array}{l}\text { 4-Hydroxy-tetrahydrodipicolinate } \\
\text { synthase }\end{array}$ & Methanosaeta concilii & $\mathrm{LT}$ \\
\hline $\begin{array}{l}\text { 5,10-Methylenetetrahydromethano- } \\
\text { pterin reductase }\end{array}$ & $\begin{array}{l}\text { Methanobacterium } \\
\text { formicicum }\end{array}$ & $\mathrm{T}$ \\
\hline \multirow{4}{*}{$\begin{array}{l}\text { ABC transporter substrate-binding } \\
\text { protein }\end{array}$} & Methanosaeta concilii & $\mathrm{T}$ \\
\hline & $\begin{array}{l}\text { Candidatus Vecturithrix } \\
\text { granuli }\end{array}$ & A \\
\hline & $\begin{array}{l}\text { Symbiobacterium ther- } \\
\text { mophilum }\end{array}$ & $\mathrm{L}$ \\
\hline & Flexilinea flocculi & $L$ \\
\hline Acetate-CoA ligase & Methanosaeta concilii & A \\
\hline $\begin{array}{l}\text { Acetyl-CoA decarbonylase/synthase } \\
\text { complex }\end{array}$ & Methanosarcina mazei & $\mathrm{T}$ \\
\hline Acetyl-CoA synthase & Methanosaeta concilii & $\mathrm{T}$ \\
\hline Adenylyl-sulfate reductase & $\begin{array}{l}\text { Candidatus Rokubacteria } \\
\text { bacterium }\end{array}$ & $\mathrm{T}$ \\
\hline $\begin{array}{l}\text { ATP-utilizing enzymes of ATP-grasp } \\
\text { superfamily (probably carboli- } \\
\text { gase) }\end{array}$ & Methanobacterium & $\mathrm{T}$ \\
\hline Benzaldehyde dehydrogenase ॥ & Mycobacterium abscessus & $\mathrm{T}$ \\
\hline \multirow{2}{*}{$\begin{array}{l}\text { C-5 cytosine-specific DNA methyl- } \\
\text { ase family protein cellulase }\end{array}$} & Clostridioides difficile & $\mathrm{T}$ \\
\hline & Methanosaeta & $\mathrm{T}$ \\
\hline $\begin{array}{l}\text { CO dehydrogenase/CO-methylating } \\
\text { acetyl-CoA synthase complex }\end{array}$ & Methanosaeta concilii & $A\llcorner T$ \\
\hline \multirow{14}{*}{$\begin{array}{l}\text { Coenzyme-B sulfoethylthiotrans- } \\
\text { ferase (also known as methyl- } \\
\text { coenzyme M reductase) }\end{array}$} & Methanobacterium flexile & $\mathrm{LT}$ \\
\hline & $\begin{array}{l}\text { Methanobacterium } \\
\text { formicicum }\end{array}$ & $\mathrm{LT}$ \\
\hline & $\begin{array}{l}\text { Methanobacterium } \\
\text { paludis }\end{array}$ & $\mathrm{LT}$ \\
\hline & $\begin{array}{l}\text { Methanobrevibacter } \\
\text { filiformis }\end{array}$ & $\mathrm{LT}$ \\
\hline & $\begin{array}{l}\text { Methanobrevibacter } \\
\text { smithii }\end{array}$ & $\mathrm{L}$ \\
\hline & Methanoculleus & $L$ \\
\hline & Methanolinea tarda & A \\
\hline & $\begin{array}{l}\text { Methanomethylovorans } \\
\text { hollandica }\end{array}$ & $\mathrm{T}$ \\
\hline & Methanoregula formica & A \\
\hline & Methanosaeta concilii & $\mathrm{A} L \mathrm{~T}$ \\
\hline & $\begin{array}{l}\text { Methanosaetaharundi- } \\
\text { nacea }\end{array}$ & $A$ \\
\hline & $\begin{array}{l}\text { Methanosaeta ther- } \\
\text { mophilaPT }\end{array}$ & $\mathrm{T}$ \\
\hline & $\begin{array}{l}\text { Methanospirillum } \\
\text { hungatei }\end{array}$ & $\mathrm{T}$ \\
\hline & Methanothermobacter & $\mathrm{LT}$ \\
\hline $\begin{array}{l}\text { Endonuclease/Exonuclease/phos- } \\
\text { phatase family protein }\end{array}$ & $\begin{array}{l}\text { Desulfobacterium vacu- } \\
\text { olatum }\end{array}$ & $\mathrm{T}$ \\
\hline $\begin{array}{l}\text { Extracellular solute-binding protein } \\
\text { family } 1\end{array}$ & $\begin{array}{l}\text { Candidatus Vecturithrix } \\
\text { granuli }\end{array}$ & A \\
\hline FAD-binding oxidoreductase & Dietzia & $\mathrm{T}$ \\
\hline Fasciclin domain protein & Methanosaeta concilii & $\mathrm{T}$ \\
\hline
\end{tabular}

Table 5 (continued)

Description
Formate dehydrogenase
Formate dehydrogenase-N
Glyceraldehyde 3-phosphate dehy-
drogenase

$\begin{array}{ll}\text { Species } & \text { Sludge } \\ \text { Methanolinea tarda } & \mathrm{A} \\ \begin{array}{l}\text { Pseudodesulfovibrio } \\ \text { indicus }\end{array} & \mathrm{A} \\ \text { Syntrophobacterfumar- } & \mathrm{A}\end{array}$

Syntrophobacter fumaroxidans

Xenoturbellabocki L

Actinomyces cardiffensis $\mathrm{L}$

Candidatus Synechococ- L

cus spongiarum

Phytophthora nicotianae L

Microbacterium LT

Arsenicicoccus bolidensis L

Cutibacterium granu- L

losum

Demequina aurantiaca L

Elusimicrobiabacterium L

Planctomycetes bacte- T

rium

Propionibacterium nam- L netense

Saccharothrix espanaensis

Serinicoccus profundi L

Tessaracoccus lapidi- $\quad \mathrm{L}$ captus

Glycerol kinase

Ketol-acid reductoisomerase

LL-diaminopimelate aminotransferase

Manganese-dependent inorganic pyrophosphatase

Methanol-cobalamin methyltransferase

Methanol-corrinoid methyltransferase

Methylmalonyl-CoA mutase

Mit domain-containing protein 1

Molecular chaperone DnaK

N5, N10-methylene tetrahydromethanopterin dehydrogenase (coenzyme F420-dependent)

Peptidase M42

Peptidylprolyl isomerase

Periplasmic-binding protein

Phosphate-binding protein

Phosphoglycerate kinase

Pyridoxal phosphate-dependent aminotransferase

Radical SAM protein

Methylacidiphilum fuma- T riolicum

Spirosoma

Methanosaeta concilii

Methanosaeta concilii

Methanosaeta concilii

Methanomethylovorans hollandica

Methanolobus profundi

Bacterium $\quad \mathrm{T}$

Ascaris suum L

Verrucomicrobiabacte- $\mathrm{T}$ rium

Methanococcusjan- $\quad T$ naschii

Methanosaeta concilii L

Microbacterium

Methanosaeta concilii T

Methanosaeta concilii $\mathrm{T}$

Propionibacterium L

Mycobacterium palustre A

Clostridium cellulovorans L

Rhodobacter capsulatus A 
Table 5 (continued)

\begin{tabular}{lll}
\hline Description & Species & Sludge \\
\hline S-layer protein & $\begin{array}{l}\text { Methanosaeta concilii } \\
\text { Methanosaeta harundi- } \\
\text { nacea } \\
\text { Leptolyngbya }\end{array}$ & $\mathrm{ALT}$ \\
$\begin{array}{l}\text { Thioesterase } \\
\text { TIGR03759 family integrating conju- } \\
\text { gative element protein }\end{array}$ & $\begin{array}{l}\text { Pseudoxanthomonas } \\
\text { spadix }\end{array}$ & $\mathrm{A}$ \\
$\begin{array}{l}\text { Transketolase domain-containing } \\
\text { protein }\end{array}$ & $\begin{array}{l}\text { Cephalotus follicularis } \\
\text { tRNA delta(2)-isopentenylpyrophos- } \\
\text { phate transferase }\end{array}$ & $\mathrm{L}$ \\
$\begin{array}{l}\text { Uncharacterized membrane protein } \\
\text { SpollM, required for sporulation }\end{array}$ & $\begin{array}{l}\text { Prevotella jejuni } \\
\text { V-type } \mathrm{H}^{+} \text {-transporting ATPase }\end{array}$ & $\mathrm{T}$ \\
\hline
\end{tabular}

FDH could also oxidize formate to produce $\mathrm{CO}_{2}$ and reducing equivalents. The beta subunit has a transmembrane domain that allows the conduction of electrons within the protein. This enzyme is probably a key enzyme to regulate the formate catabolism in granules as it can both produce and consume formate and in this way ensure that thermodynamic conditions are favourable during the degradation of organic matter (Crable et al. 2011). As this enzyme is NAD-independent and possesses its own catalyzer, it could be extracellularly active, expanding the regulation of formate in the extracellular environment. As for hydrogen, increasing formate concentration rapidly prevents its production, limiting the oxidation of substrates. This ability to excrete FDH in the extracellular environment would therefore be a considerable advantage for bacteria, since it could reduce the concentration of formate faster than its diffusion and intracellular consumption by methanogens. In such a scenario, FDH would externally produce reducing equivalents and $\mathrm{CO}_{2}$. The reducing equivalents could then be used by methanogens via DIET to reduce $\mathrm{CO}_{2}$ to methane, since Methanosaeta and Methanosarcina, in addition to acetate, are able to consume free electrons via DIET (Rotaru et al. 2014a, b). In Agropur sludge, Methanosaeta was found to represent $57 \%$ of the archaeal genera identified (Table 2). Perhaps and contrary to what was acknowledged in the past, Methanosaeta could be a major player in non-acetoclastic methanogenesis in granular sludge (Smith and Ingram-Smith 2007). Another bacterial FDH, the nitrate-inducible FDH or FDH-N, was found in Agropur sludge. This FDH-N plays a major role in the respiration of nitrate. This is likely related to the fact that Agropur sludge treats proteins-containing wastewater, and therefore, that the nitrogen cycle is more prominent than in Lassonde and Tembec sludge.
For the same reason, cellulase has been found specifically in Tembec EPS, which is in direct links with typical paper mill wastewater substrates. The role of the extracellular enzyme is likely more instrumental in a confined environment such as the innermost region of granules than in the open medium of a free suspension. This likely adds to the competitive advantages of biofilm as compared to planktonic growth.

As previously mentioned and shown here, substrate impacts bacterial populations present in granules from different origins (Table 2). It also impacts the diversity, which was much lower in Agropur sludge than in Tembec sludge, for example. Archaeal populations also vary, but the balance between acetoclastic and hydrogenophilic methanogens seems to be fairly stable despite the dissimilarity of treated wastewater. The origin of the sludge also has an impact on the characteristics of the EPS. Although approximately the same amount of HS was found in every sludge, protein and carbohydrate fractions varied more than 3 times from one sludge to another (Table 4). With regard to the different proteins identified and the microbial species that produce them, since very few structural proteins have been detected, it is difficult to relate the role of the different species present to the structural function of the EPS. However, it seems that EPS could be an important site for enzymatic reactions, since many catabolic enzymes have been found there. Further analysis is needed to understand the role of these enzymes in the ecology of granules, as very few studies have been published on the protein fraction of EPS in granules. Some studies have characterized the protein fraction of EPS only in aerobic sludge flocs and granules. The current study improved the quantification and contributed to the characterization of the EPS protein fraction for anaerobic granules expressly.

\section{Additional file}

Additional file 1: Figure S1. Measured protein concentration. Figure S2. Measured concentration of humic substances. Figure S3. Microphotographs of sonicated granules, showing alive cells. Table S1. Analysis of the protein fraction of the extracellular polymeric substances by tandem mass spectrometry.

\section{Authors' contributions}

CDD and SRG conceived the study. CDD performed the experiments. CDD and SRG wrote the manuscript. All authors read and approved the final manuscript.

\footnotetext{
Author details

${ }^{1}$ Anaerobic Bioprocesses Group, Energy, Mining and Environment Research Centre, National Research Council Canada, 6100 Royalmount Avenue, Montreal H4P 2R2, Canada. ${ }^{2}$ Department of Microbiology, Infectiology and Immunology, Université de Montréal, 2900 Boul. Édouard-Montpetit, Montreal H3T 1J4, Canada.
} 


\begin{abstract}
Acknowledgements
The authors wish to thank A. Corriveau and S. Deschamps for their support in analytical chemistry, G. Bruant and M.-J. Lévesque, for their support in DNA sequencing, F. Lépine and A. Nikolakakis (INRS-IAF) for their support in mass spectrometry, and P. Mehta, for proofreading. NRC publication No. 55918.
\end{abstract}

\section{Competing interests}

The authors declare that they have no competing interests.

\section{Availability of data and materials}

The data supporting the conclusions of this article are available and included within the article.

\section{Consent for publication}

Not applicable.

\section{Ethics approval and consent to participate}

This article does not contain any studies with human participants or animals performed by any of the authors.

\section{Funding information}

This work was partly supported by the Natural Sciences and Engineering Research Council of Canada (Grant 185778-2009).

\section{Publisher's Note}

Springer Nature remains neutral with regard to jurisdictional claims in published maps and institutional affiliations.

Received: 22 January 2019 Accepted: 30 January 2019

Published online: 07 February 2019

\section{References}

Balch WE, Fox GE, Magrum L, Woese CR, Wolfe RS (1979) Methanogens: reevaluation of a unique biological group. Microbiol Rev 43(2):260-296

Brassard J, Gottschalk M, Quessy S (2004) Cloning and purification of the Streptococcus suis serotype 2 glyceraldehyde-3-phosphate dehydrogenase and its involvement as an adhesin. Vet Microbiol 102(1-2):87-94. https:// doi.org/10.1016/j.vetmic.2004.05.008

Burton K (1956) A study of the conditions and mechanisms of the diphenylamine reaction for the colorimetric estimation of deoxyribonucleic acid. Biochem J 62(2):315-323

Cedervall PE, Dey M, Pearson AR, Ragsdale SW, Wilmot CM (2010) Structural insight into methyl-coenzyme $M$ reductase chemistry using coenzyme B analogues. Biochemistry 49(35):7683-7693. https://doi.org/10.1021/ bi100458d

Claus H, Gleixner G, Filip Z (1999) Formation of humic-like substances in mixed and pure cultures of aquatic microorganisms. Acta Hydrochim Hydrobiol 27(4):200-207. https://doi.org/10.1002/(SICI)1521-401X(19990 7)27:4\%3C200:AID-AHEH200\%3E3.0.CO;2-Q

Comte S, Guibaud G, Baudu M (2006) Relations between extraction protocols for activated sludge extracellular polymeric substances (EPS) and EPS complexation properties: Part I. Comparison of the efficiency of eight EPS extraction methods. Enzyme Microb Technol 38(1-2):237-245

Crable BR, Plugge CM, McInerney MJ, Stams AJM (2011) Formate formation and formate conversion in biological fuels production Enzyme Res 2011:1-8. https://doi.org/10.4061/2011/532536

D'Abzac P, Bordas F, van Hullebusch E, Lens PN, Guibaud G (2010) Extraction of extracellular polymeric substances (EPS) from anaerobic granular sludges: comparison of chemical and physical extraction protocols. Appl Microbiol Biotechnol 85(5):1589-1599. https://doi.org/10.1007/s0025 3-009-2288-x

De Vrieze J, Hennebel T, Boon N, Verstraete W (2012) Methanosarcina: the rediscovered methanogen for heavy duty biomethanation. Bioresour Technol 112:1-9. https://doi.org/10.1016/j.biortech.2012.02.079

Ding Z, Bourven I, Guibaud G, van Hullebusch ED, Panico A, Pirozzi F, Esposito G (2015) Role of extracellular polymeric substances (EPS) production in bioaggregation: application to wastewater treatment. Appl Microbiol Biotechnol 99(23):9883-9905. https://doi.org/10.1007/s00253-015-6964-8
Dolfing J, Mulder J-W (1985) Comparison of methane production rate and coenzyme $\mathrm{F}_{420}$ content of methanogenic consortia in anaerobic granular sludge. Appl Environ Microbiol 49(5):1142-1145

Dubois M, Gilles KA, Hamilton JK, Rebers PA, Smith F (1956) Colorimetric method for determination of sugars and related substances. Anal Chem 28(3):350-356

Eaton AD, Clesceri LS, Rice EW, Greenberg AE (eds) (2005) Standard methods for the examination of water and wastewater. American Public Health Association, American Water Works Association, Water Environment Federation, Washington, D.C

El Fantroussi SE, Naveau H, Agathos SN (1998) Anaerobic dechlorinating bacteria. Biotechnol Prog 14(2):167-188. https://doi.org/10.1021/bp980011k

Fagan RP, Fairweather NF (2014) Biogenesis and functions of bacterial S-layers. Nat Rev Microbiol 12(3):211-222. https://doi.org/10.1038/nrmicro3213

Flemming HC, Wingender J (2010) The biofilm matrix. Nat Rev Microbiol 8(9):623-633. https://doi.org/10.1038/nrmicro2415

Frølund B, Griebe T, Nielsen PH (1995) Enzymatic activity in the activatedsludge floc matrix. Appl Microbiol Biotechnol 43(4):755-761. https://doi. org/10.1007/s002530050481

Hadjeb N, Berkowitz GA (1996) Preparation of T-overhang vectors with high PCR product cloning efficiency. Biotechniques 20(1):20-22. https://doi. org/10.2144/96201bm02

Hulshoff Pol LW, de Castro Lopes SI, Lettinga G, Lens PNL (2004) Anaerobic sludge granulation. Water Res 38(6):1376-1389. https://doi.org/10.1016/j. watres.2003.12.002

Hussain A, Bruant G, Mehta P, Raghavan V, Tartakovsky B, Guiot SR (2014) Population analysis of mesophilic microbial fuel cells fed with carbon monoxide. Appl Biochem Biotechnol 172(2):713-726. https://doi.org/10.1007/ s12010-013-0556-9

Jensen HM, Albers AE, Malley KR, Londer YY, Cohen BE, Helms BA, Weigele P, Groves JT, Ajo-Franklin CM (2010) Engineering of a synthetic electron conduit in living cells. Proc Natl Acad Sci USA 107(45):19213-19218. https ://doi.org/10.1073/pnas.1009645107

Jin H, Song YP, Boel G, Kochar J, Pancholi V (2005) Group A streptococcal surface GAPDH, SDH, recognizes UPAR/CD87 as its receptor on the human pharyngeal cell and mediates bacterial adherence to host cells. J Mol Biol 350(1):27-41. https://doi.org/10.1016/j.jmb.2005.04.063

Juteau P, Beaudet R, McSween G, Lépine F, Milot S, Bisaillon JG (1995) Anaerobic biodegradation of pentachlorophenol by a methanogenic consortium. Appl Microbiol Biotechnol 44(1-2):218-224. https://doi. org/10.1007/bf00164505

Klüpfel L, Piepenbrock A, Kappler A, Sander M (2014) Humic substances as fully regenerable electron acceptors in recurrently anoxic environments. Nat Geosci 7:195. https://doi.org/10.1038/ngeo2084

Laemmli UK (1970) Cleavage of structural proteins during the assembly of the head of bacteriophage T4. Nature 227(5259):680-685. https://doi. org/10.1038/227680a0

Liu Y-Q, Liu Y, Tay J-H (2004) The effects of extracellular polymeric substances on the formation and stability of biogranules. Appl Microbiol Biotechnol 65(2):143-148

Lowry OH, Rosenburg NJ, Farr AL, Randall RJ (1951) Protein measurement with Folin reagent. J Biol Chem 103:265-275

Lu GT, Xie JR, Chen L, Hu JR, An SQ, Su HZ, Feng JX, He YQ, Jiang BL, Tang DJ, Tang JL (2009) Glyceraldehyde-3-phosphate dehydrogenase of Xanthomonas campestris pv. campestris is required for extracellular polysaccharide production and full virulence. Microbiology 155(Pt 5):1602-1612. https://doi.org/10.1099/mic.0.023762-0

MacLeod FA, Guiot SR, Costerton JW (1990) Layered structure of bacterial aggregates produced in an upflow anaerobic sludge bed and filter reactor. Appl Env Microbiol 56(6):1298-1307

MacLeod FA, Guiot SR, Costerton JW (1995) Electron microscopy examination of the extracellular polymeric substances in anaerobic granular biofilms. World J Microbiol Biotech 11(5):481-485. https://doi.org/10.1007/BF002 86356

Monique R, Elisabeth GN, Etienne P, Dominique L (2008) A high yield multimethod extraction protocol for protein quantification in activated sludge. Bioresour Technol 99(16):7464-7471. https://doi.org/10.1016/j.biort ech.2008.02.025

Moody RG, Williamson MP (2013) Structure and function of a bacterial Fasciclin I Domain Protein elucidates function of related cell adhesion proteins 
such as TGFBlp and periostin. FEBS Open Bio 3:71-77. https://doi. org/10.1016/j.fob.2013.01.001

Oliveira L, Madureira P, Andrade EB, Bouaboud A, Morello E, Ferreira P, Poyart C, Trieu-Cuot P, Dramsi S (2012) Group B Streptococcus GAPDH is released upon cell lysis, associates with bacterial surface, and induces apoptosis in murine macrophages. PLoS ONE 7(1):e29963. https://doi.org/10.1371/ journal.pone.0029963

Pancholi V, Chhatwal GS (2003) Housekeeping enzymes as virulence factors for pathogens. Int J Med Microbiol 293(6):391-401. https://doi. org/10.1078/1438-4221-00283

Park C, Helm RF (2008) Application of metaproteomic analysis for studying extracellular polymeric substances (EPS) in activated sludge flocs and their fate in sludge digestion. Water Sci Technol 57(12):2009-2015. https ://doi.org/10.2166/wst.2008.620

Park C, Novak JT, Helm RF, Ahn Y-O, Esen A (2008) Evaluation of the extracellular proteins in full-scale activated sludges. Water Res 42(14):3879-3889. https://doi.org/10.1016/j.watres.2008.05.014

Pellicer-Nàcher C, Domingo-Félez C, Mutlu AG, Smets BF (2013) Critical assessment of extracellular polymeric substances extraction methods from mixed culture biomass. Water Res 47(15):5564-5574. https://doi. org/10.1016/j.watres.2013.06.026

Picard C, Ponsonnet C, Paget E, Nesme X, Simonet P (1992) Detection and enumeration of bacteria in soil by direct DNA extraction and polymerase chain reaction. Appl Environ Microbiol 58(9):2717-2722

Ragsdale SW, Pierce E (2008) Acetogenesis and the Wood-Ljungdahl pathway of $\mathrm{CO}_{2}$ fixation. Biochim Biophys Acta 1784(12):1873-1898. https://doi. org/10.1016/j.bbapap.2008.08.012

Ras M, Lefebvre D, Derlon N, Paul E, Girbal-Neuhauser E (2011) Extracellular polymeric substances diversity of biofilms grown under contrasted environmental conditions. Water Res 45(4):1529-1538. https://doi. org/10.1016/..watres.2010.11.021

Roden EE, Kappler A, Bauer I, Jiang J, Paul A, Stoesser R, Konishi H, Xu H (2010) Extracellular electron transfer through microbial reduction of solid-phase humic substances. Nat Geosci 3(6):417-421. https://doi.org/10.1038/ ngeo870

Rotaru A-E, Shrestha PM, Liu F, Markovaite B, Chen S, Nevin KP, Lovley DR (2014a) Direct interspecies electron transfer between Geobacter metallireducens and Methanosarcina barkeri. Appl Environ Microbiol 80(15):45994605. https://doi.org/10.1128/AEM.00895-14

Rotaru A-E, Shrestha PM, Liu F, Shrestha M, Shrestha D, Embree M, Zengler K, Wardman C, Nevin KP, Lovley DR (2014b) A new model for electron flow during anaerobic digestion: direct interspecies electron transfer to Methanosaeta for the reduction of carbon dioxide to methane. Energy Environ Sci 7(1):408-415. https://doi.org/10.1039/C3EE42189A
Sara M, Sleytr UB (2000) S-Layer proteins. J Bacteriol 182(4):859-868. https:// doi.org/10.1128/jb.182.4.859-868.2000

Schmidt JJ (1986) DNA cloning: a practical approach. Biochem Educ 14(2):91. https://doi.org/10.1016/0307-4412(86)90084-1

Seidler NW (2013) GAPDH, as a virulence factor GAPDH: biological properties and diversity. Adv Exp Med Biol 985:149-178. https://doi. org/10.1007/978-94-007-4716-6 5

Sekiguchi Y, Kamagata Y, Nakamura K, Ohashi A, Harada H (1999) Fluorescence in situ hybridization using 165 rRNA-targeted oligonucleotides reveals localization of methanogens and selected uncultured bacteria in mesophilic and thermophilic sludge granules. Appl Env Microbiol 65(3):1280-1288

Sheng G-P, Yu H-Q, Li X-Y (2010) Extracellular polymeric substances (EPS) of microbial aggregates in biological wastewater treatment systems: a review. Biotechnol Adv 28(6):882-894. https://doi.org/10.1016/j.biote chadv.2010.08.001

Sleytr U, Beveridge TJ (1999) Bacterial S-layers. Trends Microbiol 7(6):253-260. https://doi.org/10.1016/s0966-842x(99)01513-9

Smith KS, Ingram-Smith C (2007) Methanosaeta, the forgotten methanogen? Trends Microbiol 15(4):150-155. https://doi.org/10.1016/j.tim.2007.02.002

Stephenson R, Patoine A, Guiot SR (1999) Effects of oxygenation and upflow liquid velocity on a coupled anaerobic/aerobic reactor system. Water Res 33(12):2855-2863. https://doi.org/10.1016/S0043-1354(98)00505-3

Tay JH, Liu QS, Liu Y (2001) The role of cellular polysaccharides in the formation and stability of aerobic granules. Lett Appl Microbiol. 33(3):222-226. https ://doi.org/10.1046/j.1472-765X.2001.00986.x

Voordeckers JW, Kim BC, Izallalen M, Lovley DR (2010) Role of Geobacter sulfurreducens outer surface c-type cytochromes in reduction of soil humic acid and anthraquinone-2,6-disulfonate. Appl Environ Microbiol 76(7):2371-2375. https://doi.org/10.1128/AEM.02250-09

Zhang L, Feng X, Zhu N, Chen J (2007) Role of extracellular protein in the formation and stability of aerobic granules. Enzyme Microb Technol 41(5):551-557. https://doi.org/10.1016/j.enzmictec.2007.05.001

Zhang P, Shen Y, Guo JS, Li C, Wang H, Chen YP, Yan P, Yang JX, Fang F (2015) Extracellular protein analysis of activated sludge and their functions in wastewater treatment plant by shotgun proteomics. Sci Rep 5:12041. https://doi.org/10.1038/srep12041

Zhu L, Zhou J, Lv M, Yu H, Zhao H, Xu X (2015) Specific component comparison of extracellular polymeric substances (EPS) in flocs and granular sludge using EEM and SDS-PAGE. Chemosphere 121:26-32. https://doi. org/10.1016/j.chemosphere.2014.10.053

\section{Submit your manuscript to a SpringerOpen ${ }^{\odot}$ journal and benefit from:}

- Convenient online submission

- Rigorous peer review

- Open access: articles freely available online

- High visibility within the field

- Retaining the copyright to your article

Submit your next manuscript at $\boldsymbol{\nabla}$ springeropen.com 